\title{
Umowa leasingu konsumenckiego
}

\author{
Consumer leasing agreement
}

\section{Wprowadzenie}

Przez długi czas umowa leasingu w systemie prawa Rzeczpospolitej Polskiej była zaliczana do umów nienazwanych. Do naszego porządku jurydycznego wprowadzono ją ustawą z dnia 26 lipca 2000 r. o zmianie ustawy - Kodeks cywilny (Dz.U. z 2000 r. Nr 74, poz. 857, dalej ustawa o zmianie ustawy - Kodeks cywilny). Popularność instytucji leasingu wśród przedsiębiorców oraz liczne korzyści wynikające z korzystania $\mathrm{z}$ tej formy finansowania przyczyniły się do wzrostu zainteresowania leasingiem przez osoby fizyczne nieprowadzące działalności gospodarczej. Ustawą z dnia 25 marca 2011 r. o ograniczaniu barier administracyjnych dla obywateli i przedsiębiorców (Dz.U. z 2011 r. Nr 106, poz. 622) w naszym systemie prawa wprowadzono zmiany dotyczące stosowania nowego rodzaju leasingu. Postępujący wzrost liczby umów leasingu, których stroną jest konsument, korelował $\mathrm{z}$ wyodrębnieniem nowego rodzaju leasingu, tj. leasingu konsumenckiego. Jednak wykreowanie tego rodzaju umowy nasuwa wiele wątpliwości związanych $\mathrm{z}$ jej statusem prawnym oraz stosowaniem w praktyce. Czy leasing konsumencki jest nowym rodzajem umowy, a może tylko dotychczas rzadko wykorzystywaną odmianą leasingu? Jakie są regulacje prawne tego typu umowy? Jakie problemy prawne występują przy stosowaniu leasingu konsumenckiego? Na takie pytania będzie starał się udzielić odpowiedzi autor tego artykułu. 


\section{Leasing konsumencki jako rodzaj leasingu}

W związku z niewielką popularnością leasingu konsumenckiego wśród leasingobiorców pojawiają się pewne wątpliwości odnoszące się do statusu prawnego umowy leasingu konsumenckiego.

Umowa leasingu była zawierana przez podmioty obrotu gospodarczego i funkcjonowała jako umowa nienazwana na podstawie zasady swobody umów (Doliwa, 2012, s. 238). Dynamiczny rozwój działalności leasingowej doprowadził do wykreowania nowego typu umowy nazwanej - umowy leasingu (Radwański \& Panowicz-Lipska, 2017, s. 153). Do naszego porządku jurydycznego została wprowadzona ustawą o zmianie ustawy - Kodeks cywilny. Ustawowa petryfikacja umowy leasingu stanowi usankcjonowanie dotychczasowej praktyki obrotu, która została ukształtowana przez jego podmioty (Wiśniewski, 2013, s. 482).

Literatura prawnicza dotycząca umowy leasingu dokonuje jego podziału na profesjonalny oraz konsumencki. O leasingu profesjonalnym jest mowa, gdy strony umowy, czyli finansujący oraz korzystający, są przedsiębiorcami, a rzecz oddana w leasing korzystającemu ma zostać wykorzystana w prowadzonej przez ten podmiot działalności gospodarczej (Brol, 2010, s. 47). Należy zwrócić uwagę, iż dotychczas występująca praktyka leasingowa była ukierunkowana tylko na ten rodzaj leasingu. W doktrynie aprobowano stanowisko potwierdzające stosowanie leasingu jedynie w obrocie profesjonalnym. W obecnym stanie prawnym, mimo że umowa leasingu należy do umów kwalifikowanych podmiotowo, wymaganie posiadania podmiotowych kwalifikacji odnosi się wyłącznie do leasingodawcy. Regulacje prawne odnoszące się do umowy leasingu nie zawierają wymogów określających atrybuty korzystającego (Turzyński, 2009, s. 26), a tym bardziej ograniczeń wykluczających zawieranie tych umów w obrocie konsumenckim (Brol, 2010, s. 48). Finansujący musi być przedsiębiorcą. Natomiast leasingobiorcą może być w zasadzie każdy (Pazdan, 2015, s. 601).

O leasingu konsumenckim jest mowa, gdy finansującym jest przedsiębiorca, natomiast korzystającym z rzeczy oddanej w leasing jest konsument (Brol, 2010, s. 47-48). Przy pomocy tej formy finansowania konsumenci uzyskują do używania lub używania i pobierania pożytków różnego rodzaju dobra konsumpcyjne w celu zaspokojenia potrzeb własnych, rodziny czy prowadzonego gospodarstwa domowego (Gołda, 2003, s. 46). Leasing konsumencki jest wykorzystywany przez konsumentów do pozyskiwania np. samochodów osobowych, instalacji technicznych do nieruchomości itp. Nazwa tego rodzaju leasingu „leasing konsumencki” jest powszechnie używana w literaturze prawniczej, jednak nie znajduje odzwierciedlenia w przepisach aktów normatywnych (Brol, 2010, 
s. 48). Definicja legalna konsumenta, usytuowana w części ogólnej kodeksu cywilnego, jest istotna dla całego systemu prawa (Mikłaszewicz, 2013, s. 384). W świetle przepisu art. $22^{1}$ ustawy z dnia 23 kwietnia 1964 r. - Kodeks cywilny (tekst jedn. Dz.U. z 2019 r., poz. 1145; dalej: kodeks cywilny lub k.c.) „[...] za konsumenta uważa się osobę fizyczną dokonującą z przedsiębiorcą czynności prawnej niezwiązanej bezpośrednio z jej działalnością gospodarczą lub zawodową". Konsumentem może być tylko osoba, która dokonuje czynności prawnej w zakresie niezwiązanym bezpośrednio z prowadzoną działalnością gospodarczą lub zawodową. Decydujące znaczenie ma brak związku czynności prawnej z przedstawioną powyżej działalnością, a nie sam fakt prowadzenia działalności. Występowanie chociażby pośredniego związku pomiędzy dokonaną czynnością prawną a prowadzoną działalnością gospodarczą lub zawodową nie wyklucza możliwości uznania danej osoby za konsumenta (Mikłaszewicz, 2013, s. 386).

W wyroku z dnia 27 września 2007 r. Wojewódzki Sąd Administracyjny we Wrocławiu stwierdził, że kwalifikacja umowy leasingu jako umowy leasingu konsumenckiego zależy od statusu osoby występującej po stronie leasingobiorcy. Zdaniem Sądu, termin „umowa leasingu konsumenckiego” odnosi się bezpośrednio do osób nieprowadzących działalności gospodarczej (wyr. WSA we Wrocławiu z dnia 27 września 2007 r., I SA/Wr 842/07). W przypadku osoby fizycznej nieprowadzącej działalności gospodarczej albo zawodowej stwierdzenie statusu konsumenta nie sprawia trudności. Jeżeli osoba fizyczna prowadzi działalność gospodarczą, może zostać uznana za konsumenta, gdy dokonuje z przedsiębiorcą czynności prawnej niezwiązanej bezpośrednio z jej działalnością gospodarczą albo zawodową (Pazdan, 2018, s. 108). Aby umowa leasingu była faktycznie umową leasingu konsumenckiego, leasingobiorcą musi być osoba fizyczna, która nie prowadzi działalności gospodarczej lub zawodowej, albo konsument.

Leasing konsumencki może występować w formie leasingu operacyjnego lub leasingu finansowego. W umowie leasingu, w którym korzystającym z rzeczy oddanej w leasing jest konsument, musi znaleźć się zastrzeżenie o rezygnacji przez finansującego z dokonywania odpisów amortyzacyjnych (Karwat, 2013, s. 207).

Umowa leasingu jest umową dwustronnie zobowiązującą, wzajemną, odpłatną (Kawałko \& Witczak, 2008, s. 670), konsensualną oraz kauzalną (Doliwa, 2012, s. 238). Powyższe cechy charakteryzują również umowę leasingu konsumenckiego. Umowa leasingu tego rodzaju może zostać zawarta na dowolny okres, przy czym musi to być czas oznaczony, natomiast suma opłat określonych w umowie leasingu konsumenckiego wraz z ewentualnie określoną w niej ceną, po której może nastąpić przeniesienie prawa własności, musi być równa co najmniej wartości początkowej rzeczy oddanej w leasing konsumencki (Russel, 2015, s. 229-238). 


\section{Podstawy stosowania leasingu konsumenckiego w prawie cywilnym}

W aktualnym stanie prawnym w Polsce nie występują odrębne regulacje prawne stanowiące jurydyczne podstawy leasingu konsumenckiego jako osobnej instytucji prawnej. Podstawy prawne zawierania umów leasingu konsumenckiego stanowią zamieszczone w kodeksie cywilnym przepisy odnoszące się do umowy leasingu. W świetle przepisu art. $709^{1}$ k.c. „przez umowę leasingu finansujący zobowiązuje się, w zakresie działalności swego przedsiębiorstwa, nabyć rzecz od oznaczonego zbywcy na warunkach określonych w tej umowie i oddać tę rzecz korzystającemu do używania albo używania i pobierania pożytków przez czas oznaczony, a korzystający zobowiązuje się zapłacić finansującemu w uzgodnionych ratach wynagrodzenie pieniężne, równe co najmniej cenie lub wynagrodzeniu z tytułu nabycia rzeczy przez finansującego".

Umowa leasingu, $\mathrm{w}$ tym umowa leasingu konsumenckiego, powinna być zawarta w formie pisemnej pod rygorem nieważności (art. $709^{2}$ k.c.).

Leasingodawca powinien wydać leasingobiorcy-konsumentowi rzecz w stanie, w jakim została wydana leasingodawcy przez zbywcę. Leasingodawca nie ponosi wobec leasingobiorcy-konsumenta odpowiedzialności za przydatność rzeczy do określonego użytku. Wydając rzecz konsumentowi leasingodawca, jest zobowiązany wydać razem z rzeczą odpis umowy zawartej ze zbywcą. Ponadto na leasingodawcy spoczywa obowiązek wydania leasingobiorcy-konsumentowi odpisów innych posiadanych dokumentów związanych z rzeczą oddawaną w leasing konsumencki, $w$ tym dokumentu gwarancyjnego uzyskanego od zbywcy lub producenta rzeczy (art. $709^{4}$ k.c.).

Leasingobiorca-konsument powinien korzystać z rzeczy w sposób określony postanowieniami umowy leasingu konsumenckiego. W przypadku braku odpowiednich zapisów w umowie korzystający powinien korzystać z rzeczy zgodnie z jej przeznaczeniem (art. $709^{9}$ k.c.).

Stroną umowy leasingu konsumenckiego zobowiązaną do zachowania rzeczy w należytym stanie jest leasingobiorca-konsument. Powinien on dokonywać konserwacji oraz napraw rzeczy, które są konieczne do zachowania jej w stanie niepogorszonym, pomijając zużycie wskutek właściwego używania rzeczy. Dodatkowo na leasingobiorcy-konsumencie spoczywa obowiązek ponoszenia ciężarów i obciążeń związanych z własnością lub jej podsiadaniem (art. $709^{7}$ k.c.).

Leasingobiorca-konsument nie może bez zgody leasingodawcy dokonywać zmian w rzeczy oddanej w leasing konsumencki, jeżeli zmiany nie są związane z jej przeznaczeniem (art. $709^{10}$ k.c.). Również bez zgody leasingodawcy 
leasingobiorca-konsument nie może przekazać rzeczy do używania osobie trzeciej (art. $709^{12}$ k.c.).

W przypadku zastrzeżenia w umowie obowiązku leasingobiorcy-konsumenta do ubezpieczenia rzeczy od jej utraty w trakcie trwania leasingu konsumenckiego, w braku odmiennych postanowień kontraktowych, korzystający z rzeczy ponosi koszty jej ubezpieczenia na ogólnie przyjętych warunkach (art. $709^{6}$ k.c.).

Leasingodawca może wypowiedzieć umowę leasingu konsumenckiego w przypadku, gdy leasingobiorca-konsument, pomimo upomnienia na piśmie przez leasingodawcę, nie dokonuje konserwacji i napraw rzeczy oddanej w leasing konsumencki, aby zachować ją w stanie niepogorszonym, korzysta $\mathrm{z}$ rzeczy w sposób sprzeczny z postanowieniami umowy, dokonuje w rzeczy zmian niezgodnych z jej przeznaczeniem bez zgody leasingodawcy. W takiej sytuacji leasingodawca ma prawo wypowiedzieć umowę leasingu konsumenckiego ze skutkiem natychmiastowym, chyba że postanowienia umowy określają termin wypowiedzenia (art. $709^{11}$ k.c.).

Zgodnie z przepisem art. $709^{17} \mathrm{k} . c$. do leasingu, $w$ tym leasingu konsumenckiego, posiłkowo należy stosować odpowiednie przepisy o najmie oraz o sprzedaży na raty zamieszczone w kodeksie cywilnym.

Należy dodać, że polskie przepisy nie są jednolite w odniesieniu do leasingu. Każda dziedzina prawa, która zawiera przepisy dotyczące tej formy finansowania inwestycji, definiuje leasing jedynie na swoje własne potrzeby (Trybala, 2004, s. 13).

\section{Jurydyczne problemy występujące przy stosowaniu leasingu konsumenckiego}

Przepis art. $709^{1}$ k.c. zawiera regulacje dotyczące tzw. leasingu pośredniego, w którym leasingodawca kupuje rzecz od zbywcy, by oddać ją do używania lub używania i pobierania pożytków leasingobiorcy (Brzozowski, 2014, s. 212).

W leasingu konsumenckim pośrednim leasingodawca dokonuje zakupu rzeczy od wytwórcy lub producenta, a następnie oddaje rzecz do używania lub używania i pobierania pożytków leasingobiorcy-konsumentowi.

Z zakupem określonego dobra wiąże się odpowiedzialność sprzedawcy wobec kupującego. Rękojmia za wady przy sprzedaży stanowi źródło wielu wątpliwości teoretycznych, a regulujące ją, występujące w różnych aktach normatywnych, przepisy są podstawą częstego występowania sporów (Falkowska, 2010, s. 17).

Wiele przepisów o rękojmi za wady przewidzianych w kodeksie cywilnym można stosować wprost do umowy leasingu konsumenckiego, jednak w niektó- 
rych przypadkach, gdy stroną umowy leasingu zostaje konsument, pojawiają się niejasności.

Zgodnie z przepisem art. 556 k.c., de lege lata sprzedawca jest odpowiedzialny wobec kupującego, jeżeli rzecz sprzedana ma wadę fizyczną lub prawną. W przypadku leasingu konsumenckiego kupującym jest leasingodawca-przedsiębiorca. Leasingobiorca-konsument nie jest stroną umowy sprzedaży rzeczy oddawanej w leasing konsumencki. W doktrynie prezentowany jest pogląd, w myśl którego o uprawnieniach z tytułu rękojmi decyduje kwalifikacja leasingodawcy-przedsiębiorcy, a nie leasingodawcy-konsumenta, gdyż to leasingodawca-przedsiębiorca jest stroną umowy sprzedaży (Nowacki, 2013, s. 1429). Wśród poglądów doktryny prezentowany jest także odmienny pogląd wskazujący, że w sytuacji, w której zakres uprawnień z tytułu wad rzeczy jest uzależniony od kwalifikacji personalnych korzystającego, powinny liczyć się kwalifikacje leasingobiorcy-konsumenta, a nie leasingodawcy (Pazdan, 2015, s. 614). Jednak na podstawie przepisu art. $709^{8} \$ 2$ k.c. z chwilą zawarcia przez leasingodawcę umowy sprzedaży ze zbywcą rzeczy ex lege następuje przejście na leasingobiorcę uprawnień z tytułu wad rzeczy przysługujących leasingodawcy względem zbywcy, z wyjątkiem uprawnienia odstąpienia przez leasingodawcę od umowy ze sprzedawcą rzeczy. Leasingobiorca-konsument nabywa uprawnienia z tytułu rękojmi za wady rzeczy w sposób wtórny (Nowacki, 2013, s. 1429).

Zachowanie uprawnień z tytułu rękojmi za wady rzeczy zależy od dokonania określonych aktów staranności (Pazdan, 2015, s. 613). Finansujący oddający rzecz konsumentowi na podstawie umowy leasingu konsumenckiego nie zawsze musi być zainteresowany rzetelnym sprawdzeniem stanu nabywanego dobra albo może nie dysponować odpowiednią wiedzą niezbędną do weryfikacji zgodności kupowanego towaru z umową. Nie można wykluczyć popełnienia przez finansującego błędu przy ocenie stanu fizycznego określonej rzeczy przy jej zakupie. Przepis art. $563 \$ 1$ k.c. wskazuje, że przy sprzedaży między przedsiębiorcami kupujący traci uprawnienia z tytułu rękojmi za wady, jeżeli nie zbadał rzeczy w czasie i w sposób przyjęty przy rzeczach tego rodzaju i nie zawiadomił niezwłocznie sprzedawcy o wadzie, a w przypadku, gdy wada wyszła na jaw dopiero później - jeżeli nie zawiadomił sprzedawcy niezwłocznie po jej stwierdzeniu.

W niektórych przypadkach nie można wykluczyć wręcz celowego działania leasingodawcy na szkodę leasingobiorcy-konsumenta. W myśl postanowień art. $709^{3}$ k.c., jeżeli rzecz nie zostanie wydana korzystającemu w ustalonym terminie na skutek okoliczności, za które ponosi on odpowiedzialność, umówione terminy płatności rat pozostają niezmienione. A contrario zmiana terminów płatności rat nastąpi, jeżeli rzecz przeznaczona do oddania w leasing konsumencki nie zosta- 
nie wydana konsumentowi na skutek okoliczności zależnych od postępowania leasingodawcy, np. w sytuacji, gdy leasingodawca nie zakupi określonego dobra w ustalonym terminie lub gdy określona rzecz może być nabyta w ustalonym terminie, jednak ma wady fizyczne, a leasingodawca, zamiast zgłosić wady fizyczne sprzedawcy, dokonuje zakupu rzeczy w celu oddania jej w leasing konsumencki, z pełną świadomością występujących w niej wad fizycznych. W takim przypadku na podstawie przepisu art. $557 \$ 1$ k.c. sprzedawca jest zwolniony od odpowiedzialności z tytułu rękojmi za wady, jeżeli kupujący wiedział o wadzie w chwili zawarcia umowy.

Wiedza finansującego o wadzie rzeczy stanowi przesłankę zwolnienia sprzedawcy od odpowiedzialności z tytułu rękojmi za wady (Pazdan, 2015, s. 612). Zgodnie z paremią rzymską nemo plus iuris ad alium transferre potest, quam ipse habet (Longchamps de Bérier, 2014, s. 39-57) leasingobiorcy-konsumentowi będą przysługiwać z tytułu rękojmi za wady rzeczy uprawnienia nabyte przez leasingodawcę-przedsiębiorcę. Na leasingobiorcę-konsumenta przechodzą uprawnienia z tytułu rękojmi za wady, które powstały na rzecz leasingodawcy, o ile leasingodawca nie utracił ich z powodu niezbadania rzeczy w czasie i w sposób przyjęty przy rzeczach określonego rodzaju. W takich okolicznościach konsument - jako słabsza strona umowy leasingu konsumenckiego - zostaje dodatkowo postawiony w jeszcze trudniejszej sytuacji, która nie stanowi negatywnego następstwa jego nieprawidłowego postępowania.

Wystąpienie przez leasingobiorcę-konsumenta do sprzedawcy rzeczy z roszczeniem o jej naprawę lub obniżenie ceny staje się bezzasadne w przypadku, gdy leasingodawca dokonał zakupu rzeczy w celu oddania jej w leasing konsumencki, z pełną świadomością występujących w niej wad fizycznych. Brak możliwości dochodzenia roszczeń z tytułu odpowiedzialności ex contractu nie stanowi przeszkody dla leasingobiorcy-konsumenta w dochodzeniu roszczeń w ogóle.

Zgodnie z przepisem art. $709^{8} \$ 1$ k.c. leasingodawca ponosi odpowiedzialność za wady rzeczy oddawanej w leasing leasingobiorcy-konsumentowi na skutek okoliczności, za które leasingodawca jest odpowiedzialny. Na tej podstawie prawnej leasingobiorca-konsument może dochodzić roszczeń z tytułu wady rzeczy oddanej w leasing konsumencki od nieuczciwego leasingodawcy, który np. podejmie się zbadania stanu rzeczy, ale zrobi to pobieżnie, jednocześnie pomijając wady możliwe do odkrycia w określonej rzeczy przy rzetelnej weryfikacji jej stanu.

Dokonując zakupu rzeczy, która ma zostać oddana w leasing konsumencki, leasingodawca powinien podjąć się skrupulatnego zbadania jej stanu w celu wykrycia ewentualnej wady jeszcze przed finalnym zakupem rzeczy i złożeniem 
podpisu na umowie sprzedaży. W doktrynie prezentowany jest pogląd, zgodnie z którym brak weryfikacji stanu nabywanej rzeczy przez leasingodawcę prowadzi do jego odpowiedzialności za powstanie wady (Gutowski, 2016, s. 851). Podobne stanowisko zajął Sąd Apelacyjny w Łodzi w wyroku z dnia 18 listopada 2014 r., stwierdzając, że leasingodawca, będąc przedsiębiorcą prowadzącym działalność gospodarczą, nabywając rzecz w celu oddania jej w leasing, powinien tę rzecz zbadać w czasie oraz w sposób przyjęty przy nabywaniu rzeczy określonego rodzaju, a w przypadku znalezienia w niej wady, bezzwłocznie powinien powiadomić o tym sprzedawcę (wyr. SA w Łodzi z dnia 18 listopada 2014 r., I ACa 1086/14). Przytoczony fragment tezy wyroku Sądu Apelacyjnego znajduje również odpowiednie zastosowanie do leasingodawcy oddającego rzecz w leasing konsumencki leasingobiorcy-konsumentowi.

Po zbadaniu rzeczy i stwierdzeniu w niej wady, kierując się zasadami staranności zawodowej, leasingodawca powinien skonsultować swoje wątpliwości ze zbywcą rzeczy oraz zwrócić się do niego o przedstawienie innej rzeczy tego samego rodzaju w celu zbadania jej stanu i - w przypadku braku zastrzeżeń finalnego jej nabycia. Dopiero takie działanie zapewniłoby należytą ochronę interesów leasingobiorcy-konsumenta i eliminowałoby powstanie odpowiedzialności leasingodawcy wobec konsumenta za wady rzeczy oddanej w leasing konsumencki.

Dodatkowo korzystający z rzeczy, dochodząc swoich roszczeń, może skorzystać z innej podstawy prawnej. W myśl postanowień art. 415 k.c. kto z winy swej drugiemu wyrządził szkodę, obowiązany jest do jej naprawienia. Naprawienie szkody wyrządzonej leasingobiorcy przez leasingodawcę z tytułu odpowiedzialności ex delicto może nastąpić, jeżeli korzystający z rzeczy oddanej w leasing będzie w stanie udowodnić, że przesłanki tej odpowiedzialności faktycznie zostały spełnione (Pazdan, 2015, s. 614). Podobnie w leasingu konsumenckim leasingobiorca-konsument może wystąpić do leasingodawcy z roszczeniem o naprawienie szkody z tytułu odpowiedzialności ex delicto, jeżeli przesłanki tej odpowiedzialności wystąpiły.

Występujące rozwiązania prawne de lege lata w systemie prawa w Polsce, usytuowane w art. $709^{8}$ k.c., art. 556 i nast. k.c. oraz w art. 415 k.c., co prawda zapewniają możliwość zaspokojenia roszczenia konsumenta z tytułu wady rzeczy oddanej w leasing konsumencki, jednak dochodzenie tego roszczenia może być czasochłonne i trudne, zwłaszcza dla leasingobiorcy-konsumenta. Mając na uwadze paremię rzymską ius est ars boni et aequi, można pokusić się o sugestię modyfikacji i wprowadzenia zmian w wybranych rozwiązaniach prawnych. Wśród uwag de lege ferenda powinien znaleźć się postulat ukształtowania rozwiązań 
prawnych w taki sposób, aby nie dopuszczały do krzywdzącego leasingobiorcę-konsumenta zwolnienia sprzedawcy od odpowiedzialności z tytułu rękojmi za wady rzeczy oddanej w leasing konsumencki przez leasingodawcę.

Proponowane zmiany de lege ferenda powinny uwzględniać nowelizację przepisu art. $709^{8}$ k.c. określającego zasady odpowiedzialności leasingodawcy z tytułu wady za rzecz względem leasingobiorcy-konsumenta. Nasuwa się na myśl rozwiązanie, które łączyłoby powstanie odpowiedzialności leasingodawcy wobec leasingobiorcy-konsumenta $\mathrm{z}$ tytułu wady rzeczy oddanej w leasing konsumencki od uprzedniego dokonania oględzin tej rzeczy przez konsumenta. Należałoby stworzyć leasingobiorcy-konsumentowi możliwość sprawdzenia stanu rzeczy, którą leasingodawca nabędzie z zamiarem oddania jej w leasing konsumencki, w celu zwiększenia szansy na wykrycie ewentualnie występującej w niej wady lub wad. Słuszny kompromis zabezpieczenia interesów leasingodawcy i leasingobiorcy-konsumenta jednocześnie może stanowić zobligowanie tych podmiotów do współpracy przy weryfikacji stanu rzeczy, która ma zostać oddana w leasing konsumencki, pod względem ewentualnie występujących w niej wad. Właściwym okresem dla przeprowadzenia weryfikacji stanu rzeczy byłby moment bezpośrednio poprzedzający zakup rzeczy przez leasingodawcę od zbywcy. Podobne rozwiązanie jest stosowane w przypadku najmu. Najemca dokonuje oceny stanu rzeczy wynajmowanej przed zawarciem umowy najmu.

W przypadku wystąpienia komplikacji z dochodzeniem uprawnień z tytułu rękojmi za wady leasingobiorca-konsument może dochodzić niektórych roszczeń również z tytułu gwarancji przy sprzedaży, o ile ta została udzielona.

Gwarancja przy sprzedaży stanowi alternatywny sposób zabezpieczenia interesów kupującego rzecz (Mojak \& Widło, 2005, s. 177). W przypadku leasingu konsumenckiego gwarancja przy sprzedaży stanowi również sposób zabezpieczenia interesów leasingobiorcy-konsumenta.

Zbywca rzeczy udziela leasingodawcy gwarancji zazwyczaj na piśmie przy zawieraniu umowy sprzedaży (Czachórski, Brzozowski, Safjan \& Skowrońska-Bocian, 2002, s. 395).

De lege lata, zgodnie z przepisem art. $577 \$ 1$ k.c., udzielenie gwarancji następuje poprzez złożenie oświadczenia gwarancyjnego, wskazującego zarówno obowiązki gwaranta, jak i uprawnienia kupującego w przypadku, gdy rzecz sprzedana nie będzie mieć właściwości wskazanych w tym oświadczeniu. $\mathrm{Na}$ podstawie przepisu art. $709^{4}$ k.c. leasingodawca wydaje korzystającemu odpis dokumentu gwarancyjnego co do jakości rzeczy, który uzyskał od jej zbywcy (wytwórcy). Z realizacją uprawnień z tytułu gwarancji przy sprzedaży nie występują komplikacje, gdy dokument gwarancji został wystawiony na okaziciela. Wtedy 
uprawnienia z tytułu gwarancji przechodzą z leasingodawcy na leasingobiorcę-konsumenta z chwilą wydania odpisu dokumentu. Wśród poglądów doktryny prezentowany jest podobny pogląd, w myśl którego w przypadku dokumentu gwarancji na okaziciela do przeniesienia tych uprawnień wystarczy jego wydanie (Wiśniewski, 2013, s. 499). W doktrynie prezentowany jest także odmienny pogląd wskazujący, że uprawnienia z tytułu wad rzeczy obejmują łącznie uprawnienia z tytułu rękojmi za wady oraz gwarancji przy sprzedaży, i przechodzą na leasingobiorcę-konsumenta na podstawie art. $709^{8}$ k.c. (Kopaczyńska-Pieczniak, 2014, s. 643). Z tym poglądem koreluje kolejny pogląd doktryny, w myśl którego wśród uprawnień z tytułu wad rzeczy należy łącznie wymienić uprawnienia z tytułu rękojmi za wady i gwarancji przy sprzedaży (Pazdan, 2015, s. 612).

Należy mieć na uwadze, że dokument gwarancji może być również wystawiony imiennie i jako podmiot uprawniony z tytułu gwarancji - wskazywać konkretną osobę. Wtedy zaś mogą pojawić się problemy z realizacją naprawy rzeczy oddanej w leasing konsumencki. W rzeczywistości Autoryzowane Serwisy Obsługi nie robią większych trudności. Przygotowując zlecenie naprawy na etapie przyjmowania np. auta do naprawy, weryfikują podmiot, któremu przysługuje prawo własności pojazdu, osobę z niego korzystającą (zamieszczają dane osobowe w zleceniu naprawy) oraz dokument gwarancyjny określający rzecz objętą ochroną gwarancyjną.

Praktyczna możliwość realizacji roszczeń z tytułu gwarancji przy sprzedaży nie eliminuje jednak teoretycznego problemu prawnego. Podstawę prawną realizacji uprawnień z tytułu gwarancji może stanowić przepis art. $709^{7} \$ 1$ k.c., w myśl którego korzystający jest zobowiązany do konserwacji rzeczy i dokonywania napraw w celu zachowania jej stanu oraz realizacji obowiązków związanych z własnością rzeczy, do których z pewnością należy dochodzenie roszczeń gwarancyjnych.

Jednak dla zapewnienia definitywnej pewności prawa w takim przypadku konieczne jest zawarcie umowy cesji uprawnień z tytułu gwarancji przy sprzedaży przysługujących leasingodawcy na leasingobiorcę-konsumenta. W doktrynie prezentowany jest pogląd, zgodnie z którym w przypadku gwarancji imiennej do przeniesienia tych uprawnień niezbędna jest umowa cesji (Wiśniewski, 2013, s. 499). Konieczność zawarcia umowy akcesoryjnej do umowy leasingu konsumenckiego prowadzi do niepotrzebnych komplikacji związanych z oddaniem rzeczy w leasing konsumencki.

De lege ferenda rozwiązania prawne leasingu należałoby poddać zmianom. Zgodnie ze stanowiskiem Sądu Najwyższego pozycja leasingobiorcy jest podobna do pozycji nabywcy dobra (towaru), co uzasadnia przyznanie leasingobior- 
cy ochrony zbliżonej do tej, jaka przysługuje kupującemu rzecz (uchwała SN z dnia 18 kwietnia 1996 r., III CZP 30/96), dlatego kolejna nowelizacja kodeksu cywilnego powinna wprowadzić modyfikacje, na mocy której ex lege, z chwilą wydania przez leasingodawcę rzeczy w leasing konsumencki leasingobiorcy-konsumentowi, powinno nastąpić przeniesienie praw z tytułu gwarancji przy sprzedaży. Podobne rozwiązanie występuje w przypadku przeniesienia uprawnień z tytułu rękojmi za wady rzeczy.

Sugerowane rozwiązanie wprowadziłoby wyraźną podstawę prawną przeniesienia praw z tytułu gwarancji przy sprzedaży przysługujących leasingodawcy na korzystającego oraz wyeliminowałoby konieczność zawierania akcesoryjnej umowy cesji.

\section{Konkluzje}

Leasing konsumencki stanowi niedocenianą konstrukcję prawną. Brak konkretnych przepisów prawnych, odnoszących się wyłącznie do leasingu konsumenckiego, stanowi barierę dla jego popularyzacji oraz dynamicznego rozwoju.

Z korzystaniem z leasingu konsumenckiego łączą się określone niedogodności dla leasingobiorcy-konsumenta, związane chociażby z rękojmią za wady czy gwarancją przy sprzedaży rzeczy, którą leasingobiorca-konsument otrzymuje w leasing konsumencki. Należy postulować zmiany wzmacniające ochronę interesów konsumenta.

Interesujący wydaje się postulat wprowadzenia dodatkowych rozwiązań prawnych precyzujących prawa i obowiązki stron umowy leasingu konsumenckiego. Takie rozwiązanie z pewnością ułatwiłoby korzystanie z leasingu konsumenckiego, przyczyniłoby się do jego popularyzacji oraz zapewniłoby ochronę interesów prawnych leasingobiorców-konsumentów.

\section{Bibliografia}

\section{Akty prawne}

Ustawa z dnia 23 kwietnia 1964 r. - Kodeks cywilny (tekst jedn. Dz.U. 2019, poz. 1145). Ustawa z dnia 26 lipca 2000 r. o zmianie ustawy - Kodeks cywilny (Dz.U. 2000, nr 74, poz. 857).

Ustawa z dnia 25 marca 2011 r. o ograniczaniu barier administracyjnych dla obywateli i przedsiębiorców (Dz.U. 2011, nr 106, poz. 622).

Uchwała SN z dnia 18 kwietnia 1996 r., III CZP 30/96, Legalis nr 29928. 


\section{Orzecznictwo}

Wyrok WSA we Wrocławiu z dnia 27 września 2007 r., I SA/Wr 842/07, Legalis nr 169972. Wyrok SA w Łodzi z dnia 18 listopada 2014 r., I ACa 1086/14, Legalis nr 1185920.

\section{Literatura}

Brol, J. (2010). Umowa leasingu. Warszawa: LexisNexis.

Brzozowski, A., Jastrzębski, J., Kaliński, M., Kocot, W. J., \& Skowrońska-Bocian, E. (2014). Zobowiązania. Czesść szczegółowa. Warszawa: Wolters Kluwer.

Czachórski, W., Brzozowski, A., Safjan, M., \& Skowrońska-Bociań, E. (2002). Zobowiazania. Zarys wykładu. Warszawa: LexisNesis.

Doliwa, A. (2012). Zobowiązania. Warszawa: C. H. Beck.

Falkowska, A. (2010). Odpowiedzialność sprzedawcy z tytułu rękojmi za wady fizyczne rzeczy. Warszawa: Wolters Kluwer.

Gołda, M. (2003). Leasing. Warszawa: Difin.

Gutowski, M. (red.) (2016). Kodeks cywilny. Tom II. Komentarz. Art. 450-1088. Warszawa: C. H. Beck.

Karwat, P. (2013). Ustalenie dochodu przedsiębiorców. Zasady ogólne. W: H. Litwińczuk (red.), Prawo podatkowe przedsiębiorców (s. 99-208). Warszawa: Wolters Kluwer.

Kawałko, A., \& Witczak, H. (2008). Prawo cywilne. Warszawa: C. H. Beck.

Kopaczyńska-Pieczniak, K. (2014). Kodeks cywilny. Komentarz LEX. Tom III. Zobowiązania. Część szczególna (red. A. Kidyba). Warszawa: Wolters Kluwer.

Longchamps de Bérier, F. (2014). Z uwag do metodologii nauki prawa prywatnego: powoływanie łacińskich reguł i maksym na przykładzie nemo plus iuris. Krakowskie Studia z Historii Państwa i Prawa, 7(1), 39-57. https://doi.org/10.44 67/20844131KS.14.002.2243

Mikłaszewicz, P. (2013). Kodeks cywilny. Komentarz. Tom I. Przepisy wprowadzajace (art. I-LXV PWKC). Część ogólna. Własność i inne prawa rzeczowe (art. 1-352 KC) (red. K. Osajda). Warszawa: C. H. Beck.

Mojak, J., \& Widło. J. (2005). Polskie prawo kontraktowe. Zarys wykładu. Warszawa: LexisNexis.

Nowacki, A. (2013). Kodeks cywilny. Komentarz. Tom II. Zobowiązania (art. 35392116 KC) (red. K. Osajda). Warszawa: C. H. Beck.

Pazdan, M. (2018). Kodeks cywilny. Tom I, Komentarz. Art. 1-44910 (red. K. Pietrzykowski). Warszawa: C. H. Beck.

Pazdan, M. (2015). Kodeks cywilny. Tom II. Komentarz. Art. 450-1088. Przepisy wprowadzające (red. K. Pietrzykowski). Warszawa: C. H. Beck.

Radwański, Z., \& Panowicz-Lipska, J. (2017). Zobowiązania - część szczegółowa. Warszawa: C. H. Beck. 
Russel, P. (2015). Wpływ zmian przepisów prawnych na rozwój leasingu konsumenckiego w Polsce. Pobrano z: https://ssl-kolegia.sgh.waw.pl/pl/KZiF/struktura/IF/ publikacje/Documents/O\%20nowy\%20lad\%20finansowy_Rekomendacje\%20 dla\%20animatorow\%20zycia\%20gospodarczego.pdf (24.06.2020).

Trybala, P. (2004). Leasing. Poradnik przedsiębiorcy. Warszawa: Polska Agencja Rozwoju Przedsiębiorczości.

Turzyński, M. (2009). Umowy leasingu w prawie bilansowym i podatkowym. Warszawa: Wolters Kluwer.

Wiśniewski, T. (2013). Kodeks cywilny. Komentarz, Tom 3 cz. 2 (red. J. Gudowski). Warszawa: LexisNexis.

\section{Streszczenie}

Artykuł przedstawia rozwój leasingu oraz leasingu konsumenckiego. W tekście omówiono jurydyczny status umowy leasingu konsumenckiego. Wskazano także podstawy prawne stosowania leasingu konsumenckiego w systemie prawa Rzeczpospolitej Polskiej. Zaprezentowano ponadto jurydyczne problemy najczęściej występujące przy korzystaniu z leasingu konsumenckiego oraz ich rozwiązania. Leasing konsumencki może stanowić sposób na zaspokojenie potrzeb członków gospodarstw domowych. Leasing prywatny może zostać wykorzystany do finansowania korzystania z dóbr uznawanych za luksusowe.

SŁOWA KLUCzOWE: leasing, leasing konsumencki, leasing prywatny

\section{Summary}

The article presents the development of leasing and consumer leasing. The article demonstrates the juridical status of the consumer leasing contract. The legal basis for using consumer leasing in the legal system of the Republic of Poland is also shown. The article presents juridical problems which occur most frequently when using consumer leasing and presents their solutions. Consumer leasing can be a way to meet the needs of household members. Private leasing can be used to finance the use of luxury goods.

KEYWORDS: leasing, consumer leasing, private leasing

\section{Nota o autorze}

Radosław Robiński - absolwent Wydziału Prawa i Administracji Uniwersytetu Mikołaja Kopernika; główne obszary działalności naukowej: kredyty i pożyczki; e-mail: radoslaw_robinski@wp.pl. 